Fellow and former Scholar of Brasenose College and a Rhodes Travelling Fellow, he taught and made distinguished contributions to chemistry, notably stereochemistry. His name is connected with two standard works, the English revision of "Richter", the second volume of which he edited, and Sidgwick's "Organic Chemistry of Nitrogen", which he revised in conjunction with Prof. Wilson Baker.

$\mathrm{He}$ served with distinction in the two World Wars, and in the second played a major part in the organization of the British Commonwealth Scientific Office in Washington, as well as serving as scientific advişer to the Supreme Allied Commander, South. East Asia. Afterwards, he became principal of the University College of the West Indies, in Jamaica, and in 1952, of the University College of the SouthWest, Exeter. It is fitting that his services were recognized by the award of the C.B.E., and later, of a knighthood.

A mere catalogue of Sir Thomas Taylor's distinguished career and singular range of achievements, however, would form an inadequate tribute, for he was a man of many parts, an impressive scholar, gifted with an acute and agile mind, which, coupled with vision and prodigious energy, marked him as an outstanding university administrator. He was a man of paradoxes as well as of parts. A vivid personality, yet modest; disconcertingly direct, yet kind; a man with clear-cut likes and dislikes, yet deploring alike fulsome praise and harsh criticism. He was a scholar with a zest for living and had a rich human understanding, with a pervasive sense of humour. Cultured, widely travelled, with a rich store of anecdote, aided by a remarkable memory, to receive his hospitality, and to listen to his witty, wellinformed conversation, was an engaging and stimulating experience.

Of his many achievements, both in his beloved Oxford and elsewhere, none can be judged greater than his leading part in the creation of the University College of the West Indies, in the form envisaged in the Irvine Report. His discharge of the duties of first principal was masterly, and won for him universal respect and admiration. All who served with him have reason to remember his wisdom, guidance and example with enduring gratitude. He faced unflinchingly the unending succession of stern tasks inevitable in the creation of a new institution of this character, and owing to his unfailing wisdom, leadership and immense drive, they were accomplished. When, in 1951, all seemed to have gone so well, the young and growing college was seared by a devastating hurricane at a most critical time. It was his courage, determination and buoyancy of spirit that did so much to allay discouragement and to re-invigorate all efforts. Despite the pressure and burden of administration, he spared no pains to come to know every member of his staff and all undergraduates, and his sympathetic guidance was always freely given.

The universities and colleges Sir William served were not alone in receiving the benefits of his scholarly gifts and administrative experience, for they were given unstintingly in the wider sphere of higher education within the British Commonwealth, and societies fostering cultural activities in many forms received his valued support, together with that of Lady Taylor. Musicians, naturalists and bird lovers with unbounded enthusiasm, their combined activities have enriched the annals of such organizations in many parts of the world.
His passing will be deeply felt by friends scattered throughout the world. To Lady Taylor, who survives him, we offer our deepest sympathy.

Norman Millott

\section{Prof. E. C. Jeffrey}

Edward Charles Jeffrey, professor of plant morphology at Harvard University, died on April 19, 1952, in his eighty-sixth year. A Canadian by birth, and a graduate of the University of Toronto, he received a doctorate from Harvard University in 1898 , and in 1902 was made a member of its Faculty. His position in the field of botanical research is attested by a list of 115 publications, and his success as a teacher is evidenced by some thirty graduate students trained under his direction and well represented among active American botanists.

Prof. Jeffrey was one of that small band of British post-Darwinian plant morphologists including Scott, Bower, Worsdell and Gwynn-Vaughan which, at the beginning of the century, set itself to reconstruct the evolutionary history of vascular plants. At the very outset of his studies, Jeffrey took up the stelar theory of van Tieghem and established it on a sound foundation. Then he began a search for valid evolutionary criteria applicable to the vegetative parts of vascular plants. He utilized the current biological doctrines of retention, reversion and recapitulation in an attempt to relegate them to their proper phyletic positions and, above all, he explored the fossil record, which he realized was the final court of appeal in evolutionary problems. $\mathrm{He}$ was a pioneer in the work on Mesozoic lignites and, incidentally, he brought the celloidin technique to a point of high precision. From the lignites it was but a step to the study of the microscopy of coal, a subject to which he devoted enormous labour. He advanced a sound anatomical interpretation and ecological explanation for the evolution of angiosperm herbs from woody ancestors. In his later years, he turned to cytogenetics and was a pioneer in the assertion that "the angiosperms are a mass of hybrids", and that an evolutionary theory based upon the cavortings of Oenothera lamarckiana was indeed a "mutation myth".

Prof. Jeffrey was a creative genius and a man of strong enthusiasms and convictions. Almost of necessity he became a controversial figure in American botany. He was a Darwinian who lived to see the superb confidence of his predecessors called in question, and their positive ideals supplanted by a mechanistic and negative outlook. Many of his conclusions ran counter to long-established views, and he met the common fate of the iconoclast. The criticisms levelled against him were often unfair and were based upon superficial understanding and wounded vanity. A policy of studied neglect was effectively applied to his work and others reaped where he had sown.

But the tide is turning, and some leading American workers are already aware of the fact that later discoveries have supported Jeffrey's views surprisingly. It is a safe prediction that the future will set his name high on the roll of those who have made permanent contributions to the philosophy of botany. Then the words of his own sturdy faith, so often repeated, will be amply justified: "Good work tells in the end".
RAY E. TORREY 